ATTHULAB:

Islamic Religion Teaching $\mathcal{E}$ Learning Journal

Volume 5 Nomor 1 Tahun 2020

http://journal.uinsgd.ac.id./index.php/atthulab/

\title{
Analisis Kemampuan Tahsin dan Tahfizh Mahasiswa Matematika, Ilmu Pengetahuan Alam (MIPA) dan Pendidikan Agama Islam (PAI)
}

\author{
Hamdan Sugilar1), Ujang Dedih'), Cecep Anwar ${ }^{3)}$, Wahyudin Darmalaksana ${ }^{4}$ \\ 1) Prodi Pendidikan Matematika \\ Email: hamdansugilar@uinsgd.ac.id \\ 2) Jurusan Pendidikan Agama Islam \\ Email: ujang.dedih@uinsgd.ac.id \\ 3) Jurusan Pendidikan Agama Islam \\ Email: cecepanwar@uinsgd.ac.id \\ 4) Prodi Ilmu Hadits \\ Email: yudi_darma@uinsgd.ac.id \\ Universitas Islam Neger Sunan Gunung Djati Bandung \\ J1. Soekarno Hatta Cimincarang Kec. Gedebage Kota Bandung, Jawa Barat, Indonesia
}

\begin{abstract}
The development of human character and personality, especially students, is one of them through the tahsin and tahfizh programs. This study aims to find out how the tahsin and tahfizh unit program and the ability of tahsin, tahfizh students majoring in Mathematics and Natural Sciences and Islamic Education. This research method is a qualitative descriptive study with the subject of 2015 student research majoring in PAI and MIPA tarbiyah and teacher training faculties in one of the in a college in the city of Bandung.. The results of the research show that the activities of tahsin and tahfizh are managed by the tahsin and tahfizh units of the faculty by involving supervisors and examiners of tahsin and tahfizh, the ability of tahsin and tahfizh of PAI and MIPA students in the good category with an average of 83.51 and tahfizh 84, 16 Students really respond to the existence of the units of tahsin and tahfizh and do not object to the obligation to memorize juz 30 as a condition of the munaqosah exam.
\end{abstract}

Keywords:

Tahsin, Tahfizh, character, personality

\begin{abstract}
Abstrak: Pengembangan karakter dan kepribadian manusia khususnya mahasiswa, salah satunya melalui program tahsin dan tahfizh. Penelitian ini bertujuan untuk mengetahui bagaimana program unit tahsin dan tahfizh dan kemampuan tahsin, tahfizh mahasiswa jurusan MIPA dan PAI. Metode penelitian ini merupakan penelitian deskriptif kualitatif dengan subjek penelitian mahasiswa angkatan 2015 jurusan PAI dan MIPA fakultas tarbiyah dan keguruan salah satu perguruan tinggi di Bandung. Adapun hasil penelitian menunjukkan bahwa kegiatan tahsin dan tahfizh dikelola oleh unit tahsin dan tahfizh fakultas dengan melibatkan dosen pembimbing dan penguji tahsin dan tahfizh, kemampaun tahsin dan tahfizh mahasiswa jurusan PAI dan MIPA pada kategori baik dengan rata-rata tahsin 83,51 dan tahfizh 84,16. Mahasiswa sangat merespon adanya unit tahsin dan tahfizh dan tidak keberatan dengan kewajiban menghapal juz 30 sebagai syarat sidang munaqosah.
\end{abstract}

Kata Kunci:

Tahsin, Tahfizh, karakter, kepribadian

DOI: http://dx.doi.org/10.15575/ath.v5i1.7244

Received: 01, 2020. Accepted: 04, 2020. Published: 04, 2020. 
Analisis Kemampuan Tahsin dan Tahfizh Mahasiswa Matematika, Ilmu Pengetahuan Alam (MIPA) dan Pendidikan Agama Islam (PAI)

\section{PENDAHULUAN}

Kemampuan membaca dan menghafal al-Quran merupakan hal sangat penting untuk diperhatikan dan diimplementasikan dalam kehidupan seperti halnya pada mahasiswa. Mahasiswa diharapkan dapat melaksanakan peran-peran teologis sosiologis, seperti menjadi imam shalat, khatib, memberi taushiah, dan peran atau tugas lain yang membutuhkan keterampilan membaca atau menghafal al-Quran dengan bacaan dan hafalan yang fasih.

Upaya untuk meningkatkan kualitas bacaan dan hafalan al-Quran mahasiswa Fakultas Tarbiyah dan Keguruan (FTK) telah dan akan terus dilakukan. Selain untuk keperluan di atas, mahasiswa dituntut memiliki bacaan dan hafalan yang fasih sebelum mengikuti munaqasyah. Hafalan minimal yang harus mereka kuasai yaitu satu juz 30/Juz 'Amma. Pada kenyataannya tidak dipungkiri bahwa sebagian mahasiswa FTK sudah hafal juz 30. Bahkan ada yang telah hafal lebih dari satu juz. Hanya saja sebagian lainnya belum hafal. Bahkan diduga masih banyak mahasiswa FTK yang kemampuan membaca saja masih kurang. Untuk itu diperlukan satu upaya khusus yang sistematis agar kemampuan bacaan dan hafalan al-Quran (tahsin-tahfizh) mahasiswa terutama juz 30 mengalami peningkatan secara signifikan.

Pembinaan dan pengujian Tahsin-Tahfizh al-Quran merupakan salah satu langkah tepat untuk mewujudkan mahasiswa dan sarjana FTK yang berkualitas (Tim Tahsin-Tahfidz, 2018). Kehadiran dan kiprahnya akan membawa manfaat bagi masyarakat sekitarnya. Pembimbingan Tahsin dan Tahfizh al-Quran merupakan salah satu bentuk layanan yang diberikan lembaga kepada mahasiswa. Tujuan utamanya meningkatkan kualitas bacaan dan hafalan. Fokus utamanya ialah Juz 30 (Juz 'Amma). Hal ini didasarkan pada salah satu ketentuan institusional UIN yang menyatakan bahwa sebelum mengikuti munaqasyah (ujian skripsi) mahasiswa harus sudah lulus tahsin tahfizh satu juz al-Quran (Juz 30). Hanya saja mahasiswa juga diberi peluang untuk menghafal selain Juz 30 itu. Karena kemampuan membaca dan menghafal al-Quran berkaitan dengan penguasaan kaidah-kaidah Ilmu Tajwid dan penerapannya, maka pengenalan dan penguatannya menjadi salah satu hal yang tidak bisa diabaikan. Kesalahan dalam membaca al-Quran salah satunya karena kurang menguasai kaidah ilmu Tajwid.

Salah satu deskripsi kualifikasi level 6 pada kerangka kualifikasi nasional Indonesia (KKNI) adalah membangun karakter dan kepribadian manusia Indonesia yaitu bertakwa kepada Tuhan Yang Maha Esa dan memiliki moral, etika dan kepribadian yang baik di dalam menyelesaikan tugasnya. Untuk membangun karakter dan kepribadian yang diharapkan sampai pada bertakwa dan memiliki moral, etika dan kepribadian yang baik perlu disusun langkah konkret berupa program atau kegiatan yang mendorong peningkatan karakter dan kepribadian yang baik salah satunya adalah prodi atau fakultas membuat sebuah unit khusus tahsin dan tahfizh, bimbingan atau praktek tilawah dan bimbingan ibadah. Tahfidz al-Quran berfungsi sebagai pengenalan, pembiasaan, dan penanaman nilai-nilai karakter mulia (Effendi, Syafrin, \& Syafri, 
2018). Pendidikan karakter dibutuhkan oleh mahasiswa serta dibutuhkan bimbingan dalam membangun karakter mahasiswa(Sugilar, Kariadinata, Farlina, \& Gunawan, 2018).

Hasil penelitian yang dilakukan Hakim menunjukkan bahwa $(58,70 \%)$ mahasiswa memiliki kemampuan yang baik dalam membaca Quran, $(24,50 \%)$ mahasiswa memiliki kemampuan sedang dan (16,80\%) mahasiswa memiliki kemampuan yang buruk dalam membaca kitab suci (Hakim, 2019: 35). Hasil penelitian tersebut dapat dijadikan acuan bahwa mahasiswa yang kemampuan sedang dan rendah berjumlah $41,30 \%$ perlu mendapatkan perhatian yang tentunya dengan adanya unit tahsin dan tahfizh pada fakultas diharapkan dapat membantu meningkatkan kemampuan tahsin dengan baik. Pertanyaannya bagaimana program tersebut dilaksanakan dan respon mahasiswa perlu diteliti lebih dalam lagi. Apakah mahasiswa masih membutuhkan pelatihan membaca dan memahami alQuran? Adapun kendala-kendala dalam tahsin Al-Qur'an di Ma'had Sunan Ampel Al-Aly Universitas Islam Negeri Maulana Malik Ibrahim Malang meliputi: (a) kurangnya alat bantu peraga, (b) ketika hari Jum'at kegiatan tidak kondusif, (c) kurangnya pemahaman tentang tujuan tahsin, (d) jumlah mahasantri yang banyak, (e) kehadiran muhassin, (f) tidak adanya silabus dan buku pedoman (Setiawan, 2015). Lebih setengah (52.43\%) mahasiswa angkatan belum mampu membaca Al-Qur'an dengan baik dan benar (Ariani \& Realita, 2015). Kondisi ini perlu disikapi serius dengan membuat regulasi dan program pembinaan tahsin dan tahfizh yang terstruktur dengan baik agar mahasiswa dibekali dengan kemampuan tahsin dan tahfizh dalam rangka meningkatkan karakter dan kepribadian yang baik.

Tujuan penelitian ini untuk menganalisis kemampuan tahsin dan tahfizh mahasiswa jurusan MIPA dan PAI bukan studi komparatif tetapi menganalisa kemampuan tersebut pada mahasiswa MIPA khususnya dan bagaimana untuk mahasiswa PAI sendiri. Tujuan lain penelitian ini adalah untuk mengetahui bagaimana pelaksanaan program Tahsin dan Tahfizh pada Fakultas Tarbiyah dan Keguruan (FTK), bagaimana kemampuan Tahsin dan Tahfizh mahasiswa jurusan PAI dan MIPA, prosentase ketepatan mahasiswa dalam menyelesaikan hapalan Alquran, analisis korelasi dan regresi kemampuan Tahsin dengan Tahfizh Al Qurannya mahasiswa FTK, dan mengetahui respon mahasiswa terhadap program tahsin dan tahfizh.

\section{Tahsin al-Quran}

Tahsin secara bahasa berasal dari kata Hassana-Yuhassinu-Tahsin yang berarti membaguskan atau membuat jadi bagus. Tahsin tilawatil al-Quran berarti membaguskan bacaan al-Quran sesuai dengan hak-haknya. Setiap hurup alQuran memiliki hak-hak yang harus dipenuhi oleh para qari (pembaca). Diantara hak-hak hurup tersebut adalah mengeluarkan hurup sesuai dengan tempat keluar dan sifatnya secara tepat dan benar. Selain itu, setiap rangkaian hurup yang tersusun menjadi kalimat juga memiliki hukum yang harus dipatuhi oleh seorang qari (pembaca). Hukum suatu kalimat dengan kalimat lain dibahas dalam ilmu tajwid. Dengan demikian bacaan al-Quran dikatakan bagus apabila 
Analisis Kemampuan Tahsin dan Tahfizh Mahasiswa Matematika, Ilmu Pengetahuan Alam (MIPA) dan Pendidikan Agama Islam (PAI)

membacanya sesuai hak-hak tempat keluar hurup (makhraj) dan sesuai pula dengan hukum kaidah ilmu tajwid. Sedangkan pengertian ilmu Tajwid adalah ilmu yang memberikan pengertian tentang hurup, baik hak setiap hurup maupun hukum-hukum baru yang timbul setelah hak hurup tersebut terpenuhi, yang terdiri dari sifat-sifat hurup, hukum mad dan sebagainya seperti tarqiq, tafkhim dan semisalnya.

Dengan demikian belajar tahsin dan tahfizh tidak akan dapat terlepas dari ilmu tajwid. Ilmu tajwid merupakan ilmu yang harus dikuasai oleh para pembelajar tahsin dan tahfizh. ilmu ini menjadi ilmu terapan dalam tilawah alQuran. Kefasihan dalam membaca dan menghafal al-Quran salah satunya faktor utamanya ialah kemampuan menguasai ilmu tajwid dan aplikasinya dalam membaca atau menghafal al-Quran.

\section{Hukum Mempelajari Tajwid/Tahsin}

Hukum mempelajari ilmu tajwid secara teori adalah fardhu kifayah. Sedangkan menerapkan ilmu tajwid dalam membaca al-Quran adalah fardhu 'ain atas setiap orang yang membaca al-Quran baik di luar maupun di dalam shalat. Perintah ini dari Allah dan Rasul-Nya.

Membaca al-Quran dengan menerapkan kaidah tajwid adalah wajib demi menjaga ashlah (kemurnian) al-Quran sebagaimana yang telah dijanjikan oleh Allah SWT, sehingga sampai kapan pun al-Quran tetap utuh dari mulai sejak diturunkan sampai kepada kita hari ini. Secara teologis, al-Quran dijaga oleh Allah SWT,

\section{Tahfizh al-Quran}

Tahfizh secara bahasa berasal dari kata haffazha - Yuhaffizhu - Tahfizhan yang berarti menghafalkan atau membuat menjadi hafal. Tahfizh al-Quran artinya upaya menghafal al-Quran yang dilakukan seorang penghafal (hâfizh $=$ huffâzh). Akar kata haffazha ialah hafazha, yang artinya menjaga atau memelihara. Para penghafal al-Quran merupakan hamba Allah yang berusaha dan berkontribusi dalam menjaga al-Quran. Kemampuan menghafal didasarkan pada kemampuan membaca. Kefasihan dalam membaca akan berkorelasi dengan kefasihan menghafalnya. Secara teologis al-Quran dijaga oleh SWT, sesuai dengan firman Allah Q.S. al-Hijr [15]: 9 berikut:

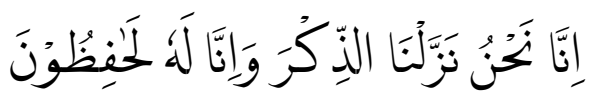

"Sesungguhnya Kami-lah yang menurunkan Al Quran, dan Sesungguhnya Kami benarbenar memeliharanya"

Ketika secara teologis al-Quran mendapat jaminan Allah untuk tetap terjaga, maka secara sosiologis manusia terlibat dalam pemeliharaan itu. Hal itu dilakukan dengan cara membaca (termasuk menghafal), dan menulisnya. Dalam al-Quran ada nama lain selain al-Quran yang banyak diulang, yaitu al-kitab. Penyebutan dua nama tersebut dengan pengulangan yang cukup banyak memberi isyarat bahwa al-Quran benar-benar terjaga dengan senantiasa dibaca (qara-a - yaqra-u -qiraatan - quran) dan ditulis (kataba - yaktubu - katban - kitaban). 
Kemampuan menghafal al-Quran merupakan nikmat dan anugrah beras dari Allah SWT. Tidak semua orang memilikinya. Orang yang fasih membaca al-Quran belum tentu hafal semua yang dibacanya. Sedangkan orang yang hafal al-Quran memiliki kemampuan membacanya. Hanya saja tetap harus diperhatikan kemampuan hafalan harus dibarengi dengan ketepatan melafalkannya. Dewasa ini tidak sedikit orang -misalnya santri/ pelajar/ mahasiswa - yang disebut hafal al-Quran dengan ukuran yang bervarasi, namun tingkat kefasihannya masih harus ditingkatkan. Dalam bahasa orang Sunda disebut hafal cangkem, artinya hafal, hanya tahsin atau tajwidnya masih kurang. Makanya sebelum menghafal, para penghafal al-Quran harus memastikan bahwa bacaannya sudah fasih. Kehadiran seorang guru untuk membimbing, mengarahkan dan meluruskna bacaan merupakan satu keharusan.

Dewasa ini kegiatan menghafal al-Quran (Tahfizh al-Quran), mendapat perhatian dari berbagai kalangan. Animo masyarakat untuk memiliki anak yang hafal al-Quran begitu tinggi. Atas dasar hal tersebut, banyak berdiri lembagalembaga pendidikan yang menjadikan kegiatan menghafal al-Quran (Tahfizh alQuran) sebagai salah satu kegiatan inti. Para ulama banyak mendirikan pondok pesantren al-Quran dengan Tahfizh al-Quran sebagai salah satu core kegiatan pendidikan dan pembelajaran. Pada saat diadakannya Musabaqah Tilawatil Quran (MTQ) dimana salah satu cabang lombanya ialah Musabaqah Hifzhil Quran (MHQ), maka sebagian besar pesertanya adalah santri atau alumi Pondok Pesantren Tahfizh al-Quran. Selain itu, sebagian besar mereka yang lulus dari pesantren tersebut kemudian mendirikan lembaga yang sama. Pada ranah pendidikan formal bermunculan Sekolah Dasar Islam Terpadu (SD-IT), Sekolah Menengah Pertama Islam Terpadu (SMP-IT), dan Sekolah Menengah Atas Islam Terpadu (SMA-IT), yang salah satu kompoenen Islam terpadunya ialah Tahfizh al-Quran.

Menghafal al-Quran merupakan kegiatan mulia, karena yang mereka hafalkan ialah kalam Allah yang agung dan pedoman hidup manusia. Keberhasilan menghafal al-Quran -apalagi kalau sampai hafal 30 juzmerupakan prestasi agung dan membanggakan. Ketika ia mewakili daerah atau negara mengikuti MHQ tingkat reginola, nasional atau internasional, hal itu merupakan langkah mulia dalam mensyi'arkan al-Quran. Apabila mereka juara, maka hal itu membawa naman baik bagi orang tua dan yang diwakilinya. Hanya saja mereka harus benar-benar memperhatikan niat dan ikhtiarnya. Niat-niat atau motivasi buruk apalagi bersifat duniawi harus dihindari. Hal penting lain yang harus benar-benar diperhatikan oleh para penghafal al-Quran ialah mempertahankan dan menambah jumlah hafalan. Beberapa hal yang harus dilakukan diantaranya:

1. Memohon pertolongan kepada Allah akan dijaga hafalannya, dengan cara banyak berdo'a dan membaca dzikir atau wirid tertentu.

2. Menjaga kebersihan hati dan pikiran. Ketika dalam hati dan pikiran terbesit hal-hal negatif atau sampai terucapkan dalam bentuk perkataan kotor, maka segera bertobat kepada Allah dan meminta maaf kepada orang yang disakiti kalau ada ucapannya yang menyakiti orang lain. 
3. Menghindari perbuatan maksiat. Hal ini yang paling utama, sebab berdasarkan penuturan para ulama -misalnya Syeikh Waqi' bin al-Jarrah yang merupakan guru Imam Syafi'i - salah satu hal yang membuat buruk hafalan ialah perbuatan maksiat.

4. Mengkonsumsi makanan yang halalan thayyiba, serta menghindari makanan yang syubhat apalagi yang haram.

5. Melakukan muraja'ah baik secara individu maupun dengan orang lain. Ketika muraja'ah dengan orang lain, maka pastikan teman muraja'ahnya itu memiliki kualitas hafalan yang lebih baik, agar dia bisa membimbing dan meluriskan setiap kesalahan dengan benar, baik yang al-Lahn alKhafy maupun al-Lahn al-Jaly.

6. Memprkatekkan semua adab dalam membaca al-Quran, karena pada dasarnya menghafal al-Quran adalah membacanya, hanya saja tanpa melihat mushaf.

Dewasa ini di tengah-tengah kehidupan masyarakat, telah banyak lembaga yang menyedaiakn jasa/ layanan pembinaan tahfizh al-Quran. Para hafizh/ hafizha yang tidak tinggal di lembaga khusus semisal pondok pesantren, bisa memanfaatkan program atau kegitana dauroh tahfizh al-Quran yang diselenggarakan oleh lembaga-lembaga tertentu. Selain itu dapat proses menghafal atau muroja' ah, para hafizh/ hafizhah dapat memanfaatkan beragam fasilitas yang sudah banyak tersedia, misalnya menggunakan teknologi audio visual. Para penerbit juga sudah banyak menerbitkan mushaf al-Quran yang secara khusus didesain untuk para penghafal al-Quran. Kalau dulu tekenal istilah "Quran Sudut" atau "Quran Pojok" dimana setiap sudut dari setiap halaman merupakan akhir ayat, maka sekarang fasilitas lain ialah mushaf alQuran dengan sistem pewarnaan yang disesuaikan dengan sejumlah ayat yang menjadi target hafalan pada setiap kali menghafal atau muraja'ah.

Selain beberapa hal yang telah diuraikan di atas, faktor penting lain yang berperan besar dalam menghafal al-Quran ialah motivasi. Motivasi bisa bersifat instrinsik/ internal yang berasal dari diri penghafal, dan ini yang paling dominan, juga bisa bersifat ekstrinsik/ eksternal. Motivasi dan do'a orang tua akan sangat berharga bagi anak dalam menghafal al-Quran. Motivasi dan do'a dari guru/ dosen akan sangat berharga bagi murid/ mahasiswa dalam menghafal al-Quran. Dalam sebuah hadits dinyatakan bahwa orang tua yang memiliki anak yang hafal al-Quran akan diberi mahkota di hari kiamat. Alangkah besar himah dan pahala menghafal al-Quran.

\section{METODE PENELITIAN}

Penelitian ini menggunakan jenis penelitian deskriptif kualitatif. Instrumen yang digunakan berupa: buku panduan dan penilaian Tahsin dan Tahfizh, angket, dan data sekunder lainnya. Subjek penelitian ini adalah mahasiswa angkatan 2015 Jurusan MIPA dan PAI FTK UIN Sunan Gunung Djati Bandung yang sedang melaksanakan bimbingan dan ujian Tahsin dan Tahfizh dan Langkah-langkah yang dilaksanakan pada penelitian ini terdiri dari, studi 
wawancara kepada kepala unit Tahsin dan Tahfizh, wawancara kepada dosen penguji Tahsin dan Tahfizh, dan wawancara kepada mahasiswa yang sedang ujian Tahsin dan Tahfizh.

\section{HASIL PENELITIAN DAN PEMBAHASAN}

\section{Pelaksanaan program Tahsin dan Tahfizh}

Pada praktenya dosen dan mahasiswa terlibat secara intens dalam kegiatan pembimbingan di atas. Keduanya mempelajari dan menerapkan kaidah-kaidah ilmu Tajwid pada setiap ayat atau surat yang dibaca/ dihafal. Ketekunan dan kesabaran dosen dalam membimbing mahasiswa yang kemampuannya beragam, merupakan salah satu kunci keberhasilannya. Selain itu ketekunan dan kesabaran mahasiswa dalam menghafal merupakan hal penting lainnya yang harus mereka lakukan. Kemampuan penguasaan materi dan metodologi yang diperoleh mahasiswa melalui kegiatan pembimbingan tahsin tahfizh al-Quran ini merupakan bekal sangat berharga ketika mereka menjadi guru. Pembimbing dan penguji dalam kegiatan ini ialah dosen FTK yang sudah menyatakan kesediaan dan di SK-kan oleh Dekan. Penguji bisa jadi dosen pembimbing langsung atau dosen lain yang ditetapkan oleh Dekan. Mereka merupakan dosen FTK yang fasih membaca al-Quran.

Mahasiswa Fakultas Tarbiyah dan Keguruan merupakan bagian dari mahasiswa UIN yang disamping diharapkan mampu menjalankan peran-peran di atas, juga memiliki kesiapan mental intelektual ketika menjadi guru, baik dilembaga pendidikan formal seperti sekolah/ madrasah maupun non formal, misalnya mengajar di pengajian-pengajian yang banyak tersebar dimasyarakat. Kemampuan membaca dan menghafal al-Quran merupakan diantara nilai tambah yang sangat berharga bagi diterimanya mahasiswa dan alumni FTK dimasyarakat. Hal itu lebih-lebih bagi mahasiswa yang secara formal dipersiapkan menjadi guru agama di sekolah atau madrasah, yaitu mahasiswa jurusan Pendidikan Agama Islam (PAI), Pendidikan Guru Madrasah Ibtidaiyah (PGMI), dan Pendidikan Bahasa Arab (PBA). Mereka nantinya akan menjadi guru PAI di SD, SMP, SMA, SMK maupun lembaga lain yang sederajat. Selain itu mereka juga akan menjadi guru Fiqh, Quran Hadits, Sejarah Kebudayaan Islam, Akidah Akhlak dan Bahasa Arab di MI, MTs, MA atau lembaga lain yang sederajat. Salah satu dimensi yang terdapat pada semua mata pelajaran tersebut ialah al-Quran dengan lima aspek pokok; yaitu bacaan/ membaca, tulisan/ menulis, hafalan/ menghafal, arti/ mengartikan, dan isi kandungan. Dua kemampuan yang lansung berkaitan dengan Pembimbingan Tahsin dan Tahfizh al-Quran di lingkungan FTK ialah membaca dan menghafal.

Tujuan Kegiatan pembimbingan tahsin dan tahfizh al-Quran adalah: menjadikan mahasiswa lebih dekat dan akrab dengan al-Quran sebagai kitab suci dan pedoman hidupnya; meningkatkan kualitas dan kuantitas bacaan dan hafalan mahasiswa FTK dan menjadikan mahasiswa memiliki kesiapan mental untuk mengikuti munaqasyah karena telah memiliki surat keterangan lulus Tahsin Tahfizh Juz 30. Peserta Kegiatan Pembinaan dan Ujian Tahsin Tahfizh ini adalah mahasiswa semester VI, dengan harapan pada akhir semester VI atau 
Analisis Kemampuan Tahsin dan Tahfizh Mahasiswa Matematika, Ilmu Pengetahuan Alam (MIPA) dan Pendidikan Agama Islam (PAI)

paling lambat semester VII mereka sudah lulus dengan nilai bagus dan memiliki surat keterangan (sertifikat). Surat keterangan lulus tersebut merupakan salah satu persyaratan yang harus dilampirkan pada saat mereka mendaftarkan diri mengikuti munaqasyah.

Mahasiswa dinyatakan lulus kalau nilai tahsin dan tahfizhnya minimal 60 . Hanya saja sangat diharap-kan pada akhir program mahasiswa memiliki bacaan dan hafalan (tahsin - tahfizh) yang baik dan benar (fasih) dengan rata-rata skor/ nilainya di atas angka 70. Berbekal kemampuan tersebut mereka dipandang layak menjadi imam shalat dan memimpin kegiatan keagamaan lainnya yang mensyaratkan kemampuan bacaan al-Quran yang baik dan benar (fasih).

\section{Kemampuan Tahsin dan Tahfizh Mahasiswa MIPA dan PAI}

Berdasarkan hasil analisis data tahsin dan tahfizh mahasiswa angkatan 2015 fakultas tarbiyah dan keguruan jurusan MIPA dan Pendidikan Agama Islam yang telah menyetorkan hapalan al-Qur'an juz 30 dan telah melaporkan secara online. Teknis setoran hapalan, mahasiswa melaporkan hapalan kepada dosen yang ditunjuk oleh unit Tahsin dan Tahfizh alQuran kemudian dosen memberikan penilaian kemampuan tahsin dan tahfizd pada buku penilaian. Mekanisme setoran hapalan yang umumnya dilakukan adalah dosen menyampaikan pemberitahuan kepada mahasiswa waktu yang telah disepakati bersama sehingga setoran mahasiswa terjadwal dengan baik. Nilai tersebut menjadi syarat dalam melaksanakan ujian munaqosah dan pengambilan ijazah. diperoleh data sebagai berikut:

Gambar 1. Jumlah Mahasiswa Angkatan 2015 yang telah Menyelesaikan Hapalan Juz 30

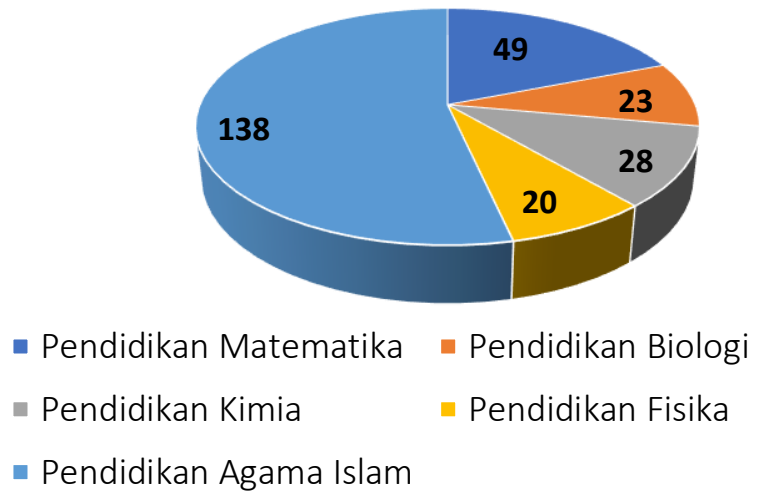

Sumber: unit tahsin tahfizh FTK data diambil tanggal 04 Juli 2019 dari data online mahasiswa

Berdasarkan gambar 1. Diperoleh bawa mahasiswa jurusan pendidikan Agama Islam yang paling banyak menyelesaikan setoran hapalan alquran. Sebanyak 138 mahasiswa angkatan 2015 atau tingkat empat telah, urutan kedua prodi pendidikan matematika, urutan ke tiga prodi pendidikan kimia, urutan ke empat prodi pendidikan biologi dan urutan ke lima prodi pendidikan fisika. 
Jurusan Pendidikan Agama Islam (PAI) dengan jumlah mahasiswa terbanyak dan bidang keagamaan yang menjadi fokus kuliahnya tahsin dan tahfizh memiliki bagian penting dan menjadi syarat wajib mahasiswa memahami tahsin dengan baik karena jurusan PAI mencetak calon guru PAI yang professional.

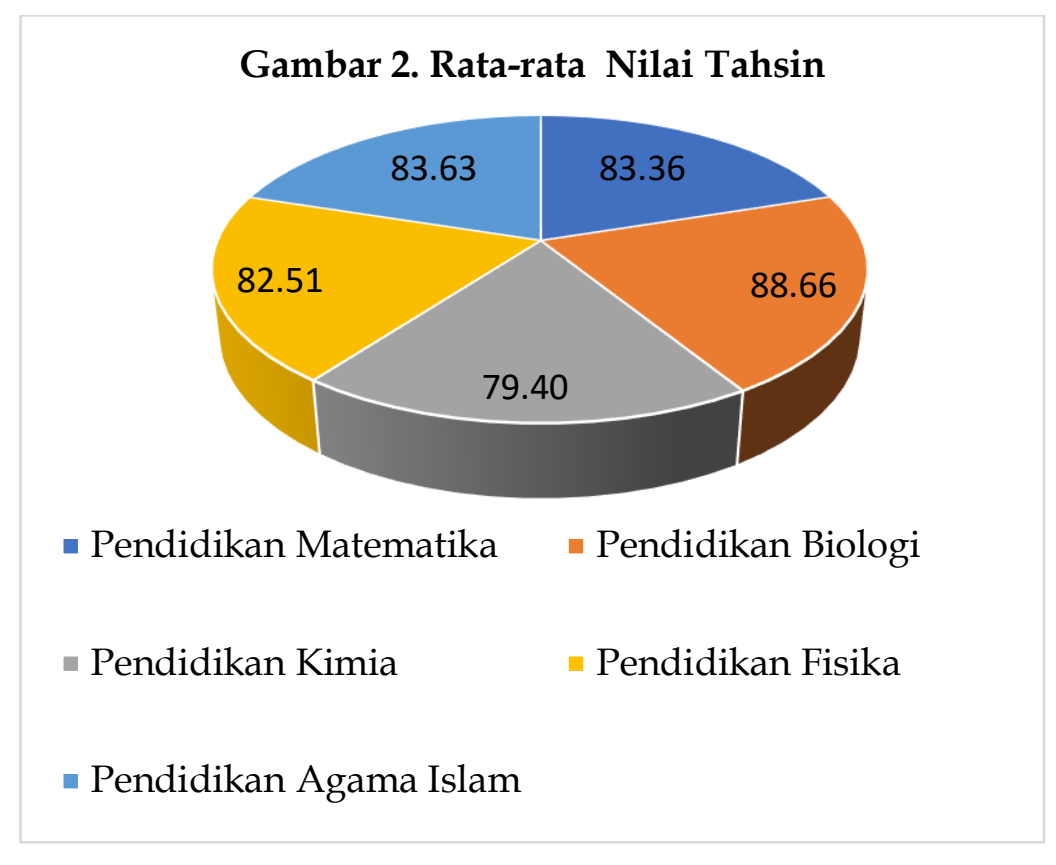

Berdasarkan gambar 2. Dapat dilihat bahwa kelima prodi tidak menunjukkan perbedaan yang signifikan kemampuan tahsin mahasiswa. Ratarata tertinggi pada prodi pendidikan biologi, sedangkan rata-rata terendah pada prodi pendidikan kimia. Faktor yang seringkali ditemukan karena mahasiswa lebih fokus pada hapalan dibandingkan dengan tahsinnya. Pada gambar 2 tersebut tidak bermaksud membandingkan kemampuan tahsin tetapi mendeskripsikan secara kuntitatif besaran nilainya tidak pada tatanan kualitatif. Faktor penyebabnya karena jumlah mahsiswa yang setor hapalan pada periode sedang dilaksanakan riset jumlahnya tidak sama. Mahasiswa yang memiliki nilai akademik baik cenderung lebih semangat untuk segera menuntaskan setoran hapalan juz 30 bahkan ada yang hapal 2, 3 bahkan ada yang hafizh. Teknik setorannya menghubungi dosen penguji yang sudah ditentukan. 
Analisis Kemampuan Tahsin dan Tahfizh Mahasiswa Matematika, Ilmu Pengetahuan Alam (MIPA) dan Pendidikan Agama Islam (PAI)

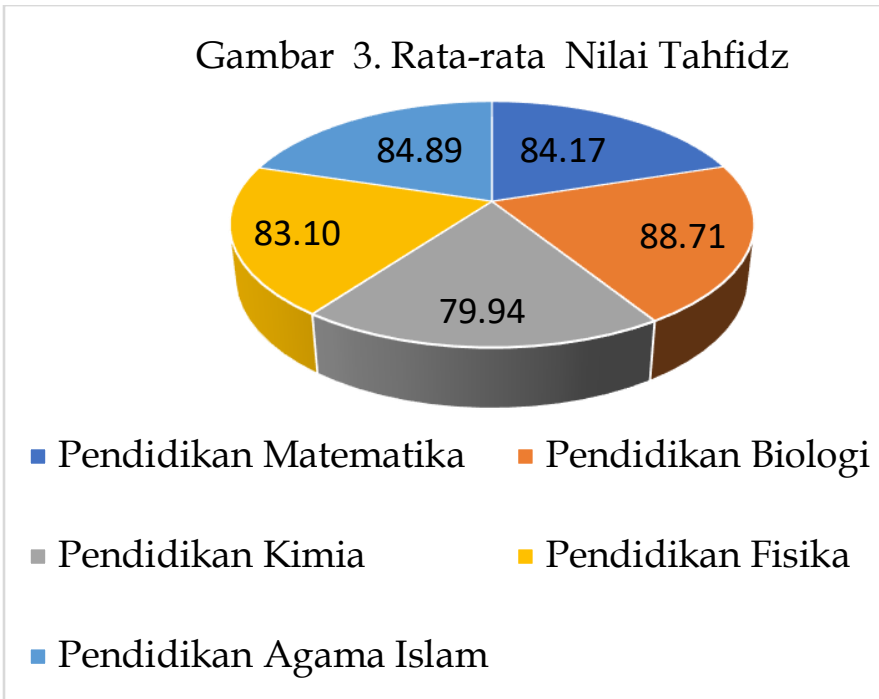

Berdasarkan gambar 3. dapat dilihat bahwa kelima prodi tidak menunjukkan perbedaan yang signifikan kemampuan tahsin mahasiswa. Ratarata nilai tahfizh tertinggi pada prodi pendidikan biologi sama begitupun dengan nilai tahsinnya mendapatkan yang tertinggi pula, karena kemampuan tahsin yang baik akan mempengaruhi kemampuan tahfizh yang baik. Sedangkan rata-rata nilai tahfizh terendah pada prodi pendidikan kimia sama halnya pada rata-rata nilai tahsinnya. Berdasarkan data tersebut menunjukkan bahwa ada hubungan positif antara kemampuan tahsin dengan kemampuan tahfizh. Nilai rata-rata tersebut diperoleh berdasarkan jumlah mahasiswa yang telah bimbingan tahsin dan menyetorkan juz 30. Jumlah mahasiswa yang bimbingan dan menyetorkan hapalan juz 30 berbeda-beda. Juz 30 merupakan regulasi yang telah ditentukan oleh fakultas sebagai syarat mengikuti ujian munaqosah, bagi mahasiswa sebagian besar tidak merasa keberatan karena sejak semester lima sudah diberikan sk pembimbing dan penguji tahsin dan tahfizh sehingga bisa menyiapkan hapalan tersebut jauh-jauh hari sebelumya. Ada pula mahasiswa yang sampai hapal $30 \mathrm{Juz}$ (hafidz/hafidzah)

Tabel 1. Simpangan Baku Data Tahsin dan Tahfizh

\begin{tabular}{lll}
\hline Jurusan/Prodi & $\begin{array}{l}\text { Simpangan Baku Data } \\
\text { Tahsin }\end{array}$ & $\begin{array}{l}\text { Simpangan Baku } \\
\text { Data Tahfizh }\end{array}$ \\
\hline Pendidikan Matematika & 4.63 & 4.34 \\
Pendidikan Biologi & 6.02 & 7.08 \\
Pendidikan Kimia & 4.06 & 5.17 \\
Pendidikan Fisika & 4.63 & 5.44 \\
Pendidikan Agama Islam & 5.17 & 6.27 \\
\hline
\end{tabular}

Berdasarkan tabel 1. dapat dilihat bahwa kelima jurusan atau prodi tidak menunjukkan perbedaan yang ekstrim kemampuan tahsin mahasiswa. Rata-rata nilai tahfizh tertinggi pada prodi pendidikan biologi sama begitupun dengan nilai tahsinnya mendapatkan yang tertinggi pula, karena kemampuan tahsin 
yang baik akan mempengaruhi kemampuan tahfizh yang baik. Sedangkan ratarata nilai tahfizh terendah tetapi masih dalam kategori baik nilai rata-rata tahsin dan tahfizh secara keseluruhannya, pada prodi pendidikan kimia sama halnya pada rata-rata nilai tahsinnya. Berdasarkan data tersebut menunjukkan bahwa ada hubungan positif antara kemampuan tahsin dengan kemampuan tahfizh.

\section{Analisis Korelasi Kemampuan Tahsin dengan Tahfizh}

Untuk mengetahui ada atau tidaknya korelasi antara kemampuan tahsin terhadap kemampuan tahfizh, kedua data tersebut diolah dan dianalisa dengan jumlah sampel sebanyak 258 mahsaiswa. Langkah pertama uji normalitas data dengan menggunakan uji Kolmogorov-Smirnov. Hipotesis yang diajukan adalah sebagai berikut:

Ho : Data X berdistribusi normal. Ha : Data X tidak berdistribusi normal.

Pengambilan keputusan: Jika Sig.(p) > 0,05 maka Ho diterima atau Jika Sig.(p) < 0,05 maka Ho ditolak. Adapun hasil perhitungan uji normalitas data dengan menggunakan bantuan SPSS, hasil uji normalitas sebagai berikut:

Karena nilai Sig.(p) < 0,05 maka Ho ditolak atau Ha diterima sehingga dapat disimpulkan bahwa data berdistribusi tidak normal. Karena data tidak berdistribusi normal selanjutnya uji korelasi dengan menggunakan uji korelasi spearman.

Korelasi antara kemampuan tahsin dengan kemampuan tahfizh: $\mathrm{r}(258)=$ 0.869; $\mathrm{p}<0.00$ berarti terdapat korelasi antara kemampuan tahsin dengan kemampuan tahfid mahasiswa jurusan MIPA dan PAI. Selanjutnya uji koefisien determinasi yaitu $r^{2}=0.869 \times 0.869=0.75$. Berdasarkan hasil analisis, kita yakin 95\% bahwa sekitar $75 \%$ variasi kemampuan tahfizh ditentukan oleh kemampuan tahsin. Terdapat $25 \%$ faktor lain yang mempengaruhi kemampuan tahfizh selain kemampuan tahsin.

\section{SIMPULAN}

Program tahsin dan tahfizh pada FTK UIN Sunan Gunung Djati Bandung yang dikelola oleh unit tahsin dan tahfizh telah berjalan dengan baik sesuai dengan program kerja yang telah disusun dengan melibatkan dosen yang bersedia menjadi pembimbing dan penguji tahsin dan tahfizh mahasiswa dapat terlayani dengan maksimal, kemampuan tahsin dan tahfizh mahasiswa jurusan PAI dan MIPA dalam kategori baik yang dapat dilihat dari nilai ujian tahsin dan tahfizh dengan jumlah mahasiswa yang sudah menyelesaikan hapalan juz 30 baru $52 \%$.

\section{REFERENSI}

Ariani, S., \& Realita, R. (2015). Program Bengkel Mengaji (Upaya Peningkatan Kemampuan Tahsin Al-Qurâ€TM an Mahasiswa PAI). Jurnal MUDARRISUNA: Media Kajian Pendidikan Agama Islam, 5(1), 113-144.

Effendi, D., Syafrin, N., \& Syafri, U. A. (2018). 5 Implementasi Pendidikan Karakter Berbasis Tahfizh al Qur'an. Prosiding Bimbingan Konseling, 40-46. 
Analisis Kemampuan Tahsin dan Tahfizh Mahasiswa Matematika, Ilmu Pengetahuan Alam (MIPA) dan Pendidikan Agama Islam (PAI)

Hakim, R. (2019). The Improvement of Students' Competence in Islamic Education Programme through Tahsin Al-Quran Activities. Khalifa Journal of Islamic Education, 3(1), 35-55.

Setiawan, D. I. (2015). Pelaksanaan kegiatan Tahsin Al-Qur'an dalam meningkatkan kemampuan membaca Al-Qur'An mahasiswa di Ma'had Sunan Ampel Al-Aly Universitas Islam Negeri Maulana Malik Ibrahim Malang.

Sugilar, H., Kariadinata, R., Farlina, E., \& Gunawan, H. (2018). Membangun Karakter Mahasiswa melalui Nilai-nilai Matematika. MaPan: Jurnal Matematika Dan Pembelajaran, 6(2), 161-172.

Tim Tahsin-Tahfidz. (2018). Buku Panduan Pembinaan dan Pengujian TahsinTahfizh. Bandung: FTK, UIN Sunan Gunung Djati Bandung. 